\title{
4 \\ Social Innovation: Redesigning the Welfare Diamond
}

Jane Jenson

\section{Introduction}

Decades of neoliberal economics and politics have resulted in major shifts in much of the world in the ways that policy and research communities now understand, shape and work to organise relations between civil society and the state and within civil society itself. Over the last fifteen years, as neoliberalism clearly revealed its limits, these communities began to deploy a range of new or reworked concepts to address ongoing challenges. Social innovation is one. Social cohesion, social inclusion and social investment are three other examples.

This chapter argues that one major contribution that the quasi-concept of social innovation has made to the world of the 'socials' is to provide a novel way to reconfigure market relations in support of social policy initiatives. This is, perhaps, not surprising since so much of the thinking about social innovation - as well as its practices - starts with reference to the work of Joseph Schumpeter (1983 [1934]). As an economist, and as the subtitle of his seminal work said, Schumpeter was most interested in 'profits, capital, credit, interest and the business cycle', the stuff of markets, in other words. Nonetheless, in his discussions of the creative destruction associated with innovation, Schumpeter was careful to consider social as well as economic and institutional factors. Nor does a gesture to Schumpeter mean that discussion of social innovation and markets has to focus narrowly. One overview of the meanings of social innovation - and examples of its practices that draws on Schumpeter includes the following: new products, new services, new processes, new markets, new platforms, new organisational forms and new business models (Caulier-Grice et al., 2012, pp. 24-5). The examples mentioned place a clear emphasis on market-making and marketshaping activities, whether by private, public or non-profit actors. 
Diagnoses of social challenges and social policy agendas have been significantly influenced by such understandings of social innovation. Much that is termed 'social innovation' or promoted by the social innovation community involves innovating in markets and with market actors to generate new well-being, even in areas usually seen as outside of the market. For example, sometimes services previously provided by governments are outsourced to not-for-profit actors such as non-governmental organisations (NGOs) that operate as market actors. Such reconfigurations also often, however, involve explicitly exposing and developing a reliance on non-market dimensions (such as community engagement and public policy) in the processes of market-making, as well as engaging social entrepreneurs in service provision. Social innovation, thus, may involve altering the very goals of markets, turning them towards purposes such as social inclusion and social development, for example, as well as repositioning the profit principle in markets for goods and services or developing a new agenda for business (Nicholls and Murdock, 2012, pp. 2-3 and passim; Osberg and Schmidpeter, 2013).

This market-expanding effect is not the only focus that a study of social innovation may have, of course. The social innovation community may also be concerned, for example, with remaking public policy instruments (see Evers et al., 2014) or with local community and grassroots efforts to remake urban space, with or without support from local government authorities (Moulaert et al., 2010).

The goal of this chapter however is to examine some of the ways that social policy makers use social innovation and social entrepreneurship to offer an alternative vision of market relations and, thereby, are engaged in redesigning the 'welfare diamond'. It does so via a review of initiatives, policies and programmes developed and deployed over the last twenty years, primarily within the borders of the European Union at supranational, national and local levels. It also considers key international actors, such as the Organisation for Economic Cooperation and Development (OECD) as well as national and local-level actors, both private and public. In doing so it provides one account of the blurred boundaries of governance.

\section{New social risks and the welfare diamond}

Social innovation is a 'quasi-concept' frequently characterised as having multiple definitions and meanings (Osberg and Schmidpeter, 2013; European Commission, 2013). As such, it is an idea with '... some reputable intellectual basis ... able to operate in both academia and policy 
domains' (McNeill, 2006, p. 335). A quasi-concept benefits from relying on academics' research but is simultaneously indeterminate enough to make it adaptable to a variety of situations and flexible enough to follow the twists and turns of policy and ideology that everyday politics sometimes makes necessary. ${ }^{1}$ Thus, as Bouchard puts it (2012, p. 50, emphasis added), social innovations may serve a variety of purposes: '... social innovations are about challenging the way responsibilities are shared between the public and the private sectors, how the social and economic dimensions are considered independently from one another in public policies, or how the global economy is distanced from local communities'.

In recent years social innovation has been deployed alongside other 'socials', all of which are quasi-concepts. ${ }^{2}$ Each has been developed in the search for ways of reordering state-society relations in the face of new social risks and new politics. Analytically, this reordering can be described as a reconfiguration of the 'welfare diamond', and in the case of the social innovation initiatives considered here, in particular the market corner of that diamond.

The welfare diamond provides a metaphor for the mixed sources of well-being experienced by everyone. ${ }^{3}$ Each corner of the diamond is a potential source of well-being and provides instruments for risk-sharing. For the majority of people, by far their major source of well-being is the market, both because of what is earned by themselves or by someone in their family, such as a spouse or a parent and because so much needed for well-being is purchased in markets (Esping-Andersen et al., 2002 , p. 11). But welfare is also derived from non-market benefits and services provided within the family. Access to welfare also comes from states or other public authorities, via public services that do not require the payment of full market prices as well as by income transfers. The fourth source is the community, whose volunteers and less than fully marketised exchanges generate welfare by providing a range of services and support, some of which are publicly financed and some of which are privately supported. These four sources of well-being can be represented in the shape of a diamond.

This conceptualisation of a welfare diamond should not be confused with notions of 'sectors' of activity, usually termed the 'private', 'public' and 'third or not-for-profit' sectors. The basis of that typology is the status of the actor, whether a private firm, a not-for-profit organisation or a public agency. The welfare diamond, in contrast, distinguishes activity by its location. Thus, for example, both a public agency and a not-forprofit association may engage in market activity by charging a fee for 
products or services, albeit perhaps without seeking a profit. A private firm may be active in the state's portion of the welfare diamond, contracting to buy or sell a product or service. Similarly, the state may shape other parts of the diamond. Nicholls (2012, pp. 230-33), for example, describes in more detail the role of public policy and foundations in building social entrepreneurship and market-making, while Sørensen and Torfing (this volume) describe the co-constitution of innovation by public, private and third-sector social innovators. According to our analytic terminology, they are describing the generation of new activities in the market or community corners of the welfare diamond.

Jurisdictions make their own choices about the content of the welfare diamond and, therefore, about the relationships across the diamond. ${ }^{4}$ It is, in fact, the intersecting relational spaces that are often the most interesting to analyse. It is important to look, for example, at how marketised relations are imported into publicly financed social services or the ways that labour markets are structured by the activities of community-based agencies (from the social economy, for example), as well as by the demand of firms.

If each jurisdiction makes choices about the welfare diamond, it also uses a variety of public and private instruments to achieve their goals. For example, even if the labour market is relied on as a primary source of income, many jurisdictions are reluctant to allow markets to distribute access to all goods and services (such as health care, post-secondary education or housing) and rely on actors in the state, family and community corners of the diamond to make a contribution to well-being. While all countries assume that parents have primary responsibility for ensuring the wellbeing of their children, some countries leave parents on their own to purchase what they can afford in the private market while others provide or subsidise low-cost or free services (childcare and housing, for example) and ensure that parents have adequate income to meet the needs of their children (whether via family allowances or other income supplements). While all countries assume that the community is the place that volunteerism will be located, some rely almost exclusively on voluntary workers, while others maintain and oversee not-for-profit groups that provide good wages and working conditions.

The economic environment around the world has changed over the last thirty years, with significant consequences for the capacity of all corners of the welfare diamond to contribute to well-being (Hall and Lamont, 2013, especially Part I). One significant development is that inequality is on the rise virtually everywhere. ${ }^{5}$ Another is that even having a job is not always a reliable source of adequate income. There are 
many people who are 'working poor', while the labour market fails to absorb vast numbers of work-seekers (Fraser, Gutierrez and Peña-Casas, 2011). The Global South is both experiencing phenomenal development in some places (with the attendant environmental and social challenges) and still facing deep poverty and hunger. Some of this is, in turn, partly but never exclusively related to socio-demographic changes, including ageing societies virtually everywhere around the world, and increases in lone-parent families (ILO, 2011). Global population flows, whether from the Global South northward or within the European Union from poorer to richer member states (whether from east to west or north to south), are also creating new wealth for some and precariousness, poverty and even misery for others (Dustmann and Frattini, 2011). Historically marginalised groups facing prejudice - Aboriginal peoples in many countries and Roma almost everywhere they live - find their lives increasingly difficult (UN, 2009; European Commission, 2011a).

Many of these changes can be summarised under the label of 'new social risks' (Bonoli and Natali, 2012). The structure of these new risks challenges previous configurations of the welfare diamond and associated social policy programmes, practices and ideas about the proper and possible balance of spaces for markets, states, families and communities. In effect, the market corner of the welfare diamond is being exhorted by social policy communities to expand, by recognising the contributions of - and contributing towards - the social economy and social entrepreneurship more generally. But often practices of social innovation also include reworking both the responsibilities of the community corner of the diamond and aligning it in ground-breaking ways with respect to the market. As it does so, social innovation's status as a quasi-concept is very clear. Numerous ways of understanding it co-exist as markets are re-imagined.

\section{Redesigning social and labour market policies by promoting social innovations}

The new social risks have provoked a variety of policy responses, and these often result in blurred boundaries. Many call for social innovators to address new social risks by expanding markets as well as by shifting relationships among markets, the community and state. ${ }^{6}$ This blurring of boundaries can happen in two ways. In some cases, while states and other public authorities continue to finance interventions to address risk, they are much less willing to design policy that involves them directly in delivery. Instead, they may turn to other actors operating 
in the market sector of the welfare diamond to form partnerships or to deliver the service according to a contract with public authorities. The second way that the market corner of the welfare diamond is bolstered is by supporting social enterprises of many types, because they are seen as more capable of meeting current needs than either the state or private sector firms. Several policy areas illustrate this direction of change. However, labour markets are probably the key domain in which marketbuilding with the support of social policy has occurred.

The drivers behind policy interest in social innovation within labour markets rests on the recognition that it is no longer possible to count on traditional firms and labour markets to provide an adequate supply of jobs and to match supply to demand for workers. After 1945, the labour market appeared to operate more smoothly, seeming to create an adequate supply of jobs and absorbing most (male) jobseekers. Public policy makers could confine their market-shaping role to regulations about hiring and working conditions, as well as unemployment insurance for those without a job for a short while. The market also provided an expanding array of goods and services. Now and for the last few decades, however, growing needs for many kinds of new services as well as job creation and job-matching, as labour markets have tightened, have become major preoccupations within social policy communities. The previous seemingly smooth operation of the labour market and of service provision can no longer be assumed. This is due to the combined effects of technological change, which has reduced demand for workers in many firms and industries, and the new social risks generated by largescale social trends such as increased inequality, social exclusion, ageing populations and demographic change. In addition, austerity-driven public policies have brought cutbacks in public-sector employment, a major source of jobs in the post-1945 years. Faced with these challenges, policy makers have turned to fostering and supporting market actors such as social enterprises and a social economy that they hope can simultaneously achieve three objectives: to help to train and prepare workers touched by the social risks to enter paid employment (supply) and to increase the labour market's need for workers (demand) by expanding and better organising markets for goods and services (supply) that the traditional firm in the private sector does not adequately offer. This third contribution is often associated with 'green' products or welfare services, but many types of services might be provided in these new markets.

Policy makers concerned with the levels and rates of employment in contemporary societies have seen social enterprises as job creators as well as 'work integration enterprises' (Evers et al., 2014, pp. 15-16). Initiatives 
often coming from the community sector of the welfare diamond may seek to shape either - and sometimes both - the supply and demand structures of labour markets, increasingly with the support of public authorities. On the supply side, and usually as part of an agenda around social inclusion, social enterprises can work to enable young people, women, immigrants and the long-term unemployed to enter the labour market. Such efforts rely on a variety of legal forms and can be seen as 'new expressions of organized civil society' (Vidal, 2005, p. 807). These enterprises can be an instrument for the achievement of the 'activation' commitment of European social and economic policy (Evers and Guillemard, 2012, Chapter 7). On the demand side, social enterprises and the social economy more generally - are often tasked with filling gaps in services that do not attract investment by traditional private-sector firms. These new service providers meet growing societal needs and, in the process, create employment. In this context, social innovation can address existing gaps in the market corner of the welfare diamond and, particularly, its failure adequately to provide work, income and inclusion as well as products and services. In these ways, social innovation can also invoke other quasi-concepts, such as social inclusion or social cohesion.

Some examples serve to illustrate various perspectives on social and labour market policy. The OECD has long been concerned with promoting higher employment rates but has also increasingly become cognisant of market imperfections (Mahon and McBride, 2008). It has been actively constructing an analysis of how to address social challenges around employment by relying on social innovation (Noya, 2011). Since its 2005 edition, the OECD's Oslo Manual has recognised a social dimension to innovation. While its Innovation Strategy still primarily focuses on standard approaches and measures of innovation, social innovation has received some attention when 'global and social challenges' are raised, while social enterprises have been discussed as an instrument of response to such challenges (OECD, 2010a: 182ff; 2010b: Chapter 5). Deployment of the quasi-concept is, in other words, an alternative way of doing entrepreneurship, management and finance. This can be interpreted as a call for greater interaction across the market and community corners of the welfare diamond - perhaps including a blurring of boundary distinctions.

This turn to social innovation is evident in the OECD's efforts to foster development of labour markets and its analysis of the failure of these markets to provide sufficient well-being for all. An analysis of policy documents and initiatives shows that, while there is a range of ideas about social innovation, one strategy in which the OECD has invested 
significantly, as part of its concern with the levels and conditions of employment, involves emphasising community-based actions to ensure greater inclusion via local partnerships that innovate in economic governance and employment creation. ${ }^{7}$ For example, the OECD's Local Economic and Employment Development (LEED) programme has as its mission to contribute to the creation of more and better jobs via innovative policy as well as effective implementation and coordinated strategies. ${ }^{8}$

In 2000, the programme launched its Forum on Social Innovations, framed explicitly around the notion of improving well-being, ${ }^{9}$ and developed an officially legitimated definition of social innovation that extended that of the Oslo Manual. ${ }^{10}$ In this definition, social innovation involves 'conceptual, process or product change, organisational change and changes in financing, and new relationships with stakeholders and territories'. The value added by social innovations is that they can, according to the Forum on Social Innovations, both innovate in services and help in 'identifying and implementing new labour market integration processes, new competencies, new jobs, and new forms of participation, as diverse elements that each contribute to improving the position of individuals in the workforce'. Concretely, this has supported the promotion of social entrepreneurship and social economy organisations, by identifying and celebrating their potential for job creation. ${ }^{11}$ LEED provides expert teams of advisors to jurisdictions seeking to put such innovations into place.

Of course the OECD is not alone in seeing social entrepreneurs and their market behaviour as significant within the wider economy. The European Union has also been moving in this direction particularly since the 2008 economic crisis. The European Union launched its Social Business Initiative (SBI) in 2011 (European Commission, 2011b). Initially, the potential for 'social business' was broadly cast to include all types of firms from multinationals to social enterprises. ${ }^{12}$ Quickly, however, the SBI narrowed down ${ }^{13}$ to focus only on social entrepreneurs and their businesses, valued because 'social enterprises seek to serve the community's interest (social, societal, environmental objectives) rather than profit maximisation. They often have an innovative nature, through the goods or services they offer, and through the organisation or production methods they resort to ...'. ${ }^{14}$ The promise of social innovations and social enterprise was incorporated into the European Union's Europe 2020 strategy. ${ }^{15}$ Moreover, a series of high-profile interventions have signalled that the European Union shares the views of those who see a greater role for social enterprises in achieving its targets 
for social inclusion and poverty reduction via their potential for job creation and new innovative services. It contributes to encouraging and supporting such new market actors via actions such as the 2014 conference on 'Empowering social entrepreneurs for innovation, inclusive growth and jobs'. At that event, workshops focused on the 'potential of social enterprises for job creation and green economy' as well as on the ways that the European Union could use its structural funds to support and foster social enterprises. ${ }^{16}$ Leverage for jobs, social inclusion and green initiatives were all identified as necessary because they are inadequately addressed by traditional firms.

Nor is it only international or supranational organisations that engage in behaviour meant to structure labour markets, both on the supply and demand sides. The major cross-national study of social cohesion and innovation reported in Evers et al. (2014) documented that 'work integration enterprises' were the most common innovation in local welfare systems. These kinds of businesses exist at the blurry boundary between market and community, often difficult to distinguish from the kinds of community groups, third-sector providers and associations that engage in social development projects, frequently at the local level (Moulaert et al., 2010).

Social policy communities' enthusiasm for the market participation of social entrepreneurs and the social economy has had to go beyond cheer-leading and publicising best practices, of course. The reconfiguration of the welfare diamond has necessitated attention to how social innovations will be financed. This need has resulted in blurring of boundaries between public and private governance as public funds flow into the market corner of the welfare diamond to finance, in whole or in part, services that are no longer public services in the classic meaning of the term, that is provided by public employees at no cost (or little cost) to users. 'Many if not most of the SIs [social innovations] we dealt with rely on a multiplicity of resources and their combination; the mix may vary and state financing may often be the most important component, but in most cases there is a degree of (financial) co-responsibility of other organizations from the civil society or the business sector' (Evers et al., 2014, p. 22). In other words, local, regional, national or European public authorities were actively using their available funds to foster local innovations in labour markets and for services. They were engaged in market-making and in blurring traditional boundaries between public and other forms of services.

Developments in childcare services provide another good example of this blurring, which has intensified as the 'social investment 
perspective' has taken over more and more of social policy discourse. ${ }^{17}$ Where the social investment perspective has been implemented, new public spending has been made and services have been expanded. And indeed, these social investment interventions continued even during the first five years of the economic crisis (Kvist, 2013). However, much of this growth has been achieved via reliance on social enterprises, considered to be most innovative.

The social investment perspective on modernising social policy ${ }^{18}$ diagnoses the challenges facing families with children and prescribes strategies to increase parental employment as well as to provide services focussed on the human capital of children in order to 'break the intergenerational cycle of disadvantage'. ${ }^{19}$ The social policy analysis underpinning the social investment perspective rests on two main themes (Esping-Andersen et al., 2002; Jenson, 2012). The first is that it is better for children that their parents are employed than that the family is workless. Following from this perspective, lone mothers and underemployed mothers are a prime target for integration into the labour force and, therefore, as clients of the work integration enterprises described above. The second theme is that the emerging knowledgebased economy requires significant investment in human capital and that this must begin with the youngest children and early childhood education. This focus is examined here.

Childcare services have expanded significantly across Europe, with stable or greater public financing of childcare services between 1998 and 2009 in every European country except Luxembourg (OECD, 2014, PF3.1). Nonetheless, while spending increased or remained at least stable, many jurisdictions reduced or limited their own direct service provision and provided incentives to social enterprises to organise services. Thus, public funding has gone to non-public actors to develop services needed to implement the social investment perspective.

For example, Sweden is a country often identified as an early adopter of the social investment perspective (Esping-Andersen et al., 2002). In the 1980s it began to innovate in forms of service provision in the name of 'choice' (Blomqvist, 2004) ${ }^{20}$ With respect to services for children, this involved reducing the dominant position of the municipal childcare centre, which had been virtually the only form of service provision used when the system expanded from the 1960s. ${ }^{21}$ In the 1980s, Sweden turned to parental and personnel cooperatives to broaden the variety of childcare (Duane-Richard and Mahon, 2001). By the 1990s, the range of providers widened again. Changes to legislation at the time meant that most municipalities would continue to provide services directly, 
but they would also be responsible for overseeing the conditions and quality of non-municipal services and non-public providers, both commercial and non-profit (OECD, 2005, p. 96).

Permission to establish private pre-schools (as childcare centres are called in Sweden) that would receive public funding similar to that of municipal centres was instituted in 1984 . The form of private provision that inspired this social innovation was the parental cooperative. Since that time, reliance on publicly funded pre-school provided by institutions other than the municipal childcare centre has expanded significantly. A market in childcare grew slowly but steadily.22 By 2006, across Sweden the number of children attending a private preschool was $17 \%$; the parental cooperative remained the most usual form (Korpi, 2007, p. 55). However, the share of service provided by private pre-schools ranged from $0 \%$ to $47 \%$, depending on the municipality. The higher share was concentrated in urban areas and better-off neighbourhoods (Blomqvist, 2004, p. 150).

The United Kingdom, after 1997, was a convert to the social investment perspective (Dobrowolsky and Jenson, 2005). The pattern of social innovations in the childcare domain has differed from that of Sweden, however, because the United Kingdom has historically been one of the European countries that relied most on private forms of financing services as well as for providing them (OECD, 2005, p. 93). The 1998 National Childcare Strategy extended an entitlement to free part-time provision for three- and four-year-olds. Funding for childcare provision was increased, and there was recognition of the need to expand the number of spaces available, via both public provision and private and voluntary sectors and via social enterprises. The new funds could be used to finance state, private and not-for-profit providers, and there was an emphasis on cross-sector planning and cooperation. While local authorities in England were 'expected to develop, plan and coordinate childcare and early years services', there was a specific emphasis on working with partners across sectors, 'including local community representatives, Jobcentre Plus, schools, health agencies, NGOs and commercial private childcare providers' (OECD, 2005, p. 99). Several incentives provided support for the development of the childcare market via social enterprises such as worker or parent cooperatives, service cooperatives, community nurseries, and so on (SEL, 2002). Lyon and Fernandez (2012, p. 4) found that in 2009 , ' $73 \%$ of the 15,600 full day care nurseries in the UK [were] in the private sector, $15 \%$ in the voluntary sector and $12 \%$ in the public sector'. Other research suggested that 'within the private childcare sector, there are many small businesses with a welldeveloped social ethic and purpose' (Capacity, 2008, p. 4). 
These two examples reflect the recognition that social entrepreneurs hoping to operate social enterprises may have difficulty obtaining adequate financing. In addition to the transfer of public funds described for both Sweden and Britain, other institutions, particularly banks, can be tapped to finance social innovations in these policy domains. For example, a stakeholder for EU consultations on these issues is the Fédération européenne des banques éthiques et alternatives (FEBEA - European Federation of Ethical and Alternative Banks), a network of banks, savings and loan cooperatives, investment companies and foundations, sharing information about their innovations in financial instruments. ${ }^{23}$ Cooperatives and other forms of alternative banking have a long history, often arising in the late 19th century to meet the needs of local communities without access to services or groups, such as farmers, whose pooling of risk was complicated. Now the form is often used to provide 'socially responsible investing' (an overview is given in Geobey et al., 2012). Such rejigging of the market relations of investment managers - whether in banks or in other firms is one way of growing the funding for social innovation. Among other things, they may provide help to social entrepreneurs with their business plans. For example, Babies and Bosses (OECD, 2005, p. 23) pointed to a problem in the British childcare system. Providers would '... too often close down after start-up funds run out, as business plans were based on unrealistic expectations about demand or over-optimistic cost assumptions'. Advice from a banking institution knowledgeable about social enterprises and the social economy could be of great help.

All these strategies are responses to the recognition that, in many situations, traditional market practices and institutions have proven themselves inadequate to the task of financing social innovation while public funding is one of the possible sources of finance for the enterprises working within the market corner of the welfare diamond.

\section{Conclusion}

This chapter has argued that social policy communities across Europe have participated in the reconfiguration of the welfare diamond. They have faced a set of challenges laid down by the appearance of new social risks among which are rising poverty rates, changing family norms and lone-parenthood, an inadequate supply of jobs and problems of labour market integration. Seeking to improve social inclusion and social cohesion, social policy communities have adopted 
strategies for prompting, promoting and supporting social innovations in the market. They have turned to social entrepreneurs to alter patterns of demand and supply in labour markets. The hope is to improve labour supply by funding and promoting social enterprises engaged in training and retraining the hard-to-employ, those excluded from the labour market or those without the necessary skills. Social policy communities have also sought to increase demand for workers by supporting the creation of many types of social enterprises that provide, often in the welfare and environmental sectors, for needs that go unmet or services that are not equally accessible when only commercial firms are active in their provision. They have also turned to social entrepreneurs to provide the key services identified by the social investment perspective for modern social policy. These are not only employment services but also childcare that serves the double function of enabling parental labour market participation and, even more importantly from this perspective, adequate investments in human capital from the pre-school years onwards via accessible and high-quality early education and care.

Social innovations, especially social entrepreneurship and quasimarkets, are now and increasingly presented as positive ways to do social interventions, avoiding the limits of both 'big business' driven by profitseeking and 'big government' driven by the practices and controls of Weberian-style public administrations. Thus, as the claims increasingly go, effective social investments will be more likely, at least to be identified and first implemented, if they are left to these market-making and market-modelled innovators. A range of mechanisms and policy instruments have been deployed across different jurisdictions, but many share the characteristic that they allow the market corner of the welfare diamond to expand by becoming more active in the provision of services. One key way that this move has been undertaken - usually at the local level - is by providing public funds for provision of what might have been or used to be public services. Thus, community-based social entrepreneurs have increasingly provided employment integration services or immigration integration services which in the past - if provided - were usually public. Similarly, as childcare services have increased significantly in number and the amount of public spending on them has risen concomitantly, the dominant position of public provision has given way to a multitude of market-based actors often operating as social enterprises in many countries. Such changes constitute significant change in the relations between state and civil society and within civil society itself. 


\section{Notes}

1. Linguists focus on these same dimensions. They recognise quasi-concepts' polysemy and describe such concepts as those which are not yet stabilised or are in the process of being destabilised (Bartsch, 2002, p. 50). For a more elaborate presentation of social innovation as a quasi-concept, see European Commission (2013).

2. In this group are other useful notions such as social cohesion (Jenson, 2010a; Bernard, 1999), social investment (Jenson, 2010b), social inclusion (Levitas, 2005) and social capital (McNeill, 2006).

3. The notion of welfare diamond presented here is clearly an extension of Gøsta Esping-Andersen's popular 'welfare triangle', which identifies the state, market and family as the three sources of well-being. I believe that it is a mistake and misleading to try, as he did, to subsume the welfare-generating community sector under the family corner of the triangle and to restrict the production of welfare to 'markets (purchased welfare), families (the reciprocity of kin) and government (solidarity)' (Esping-Andersen, et al., 2002, p. 4). Hence I propose a welfare mix with four corners that make a diamond. For this representation, see also Evers, Pijl and Ungerson (1994) as well as Evers and Guillemard (2012).

4. The recognition that there is no single form led, among other conceptual exercises, to the large literature on welfare regimes (e.g., Esping-Andersen et al., 2002) and welfare mix (e.g., Evers and Guillemard, 2012). For a recent review of the results of such choices in local welfare systems, see Evers, Ewert and Brandsen (2014).

5. The OECD has been tracking mounting inequalities both in the OECD world and in the Global South for almost a decade. See, for example, OECD (2011, p. 22).

6. For one recent discussion of such examples, see Nicholls and Murdock (2012, especially Chapters $3,5,6$ ).

7. It is interesting to note than an early precursor was Piore and Sabel's Second Industrial Divide (1984), which argued that innovation for the late 20th century could come not from firms organised around the social relations of Fordism but from those harking back to the 19th century's personalised social relations of craft production. A decade later, Charles Sabel led the team assessing the potential for social innovation of the Irish Government's experimental 'creation of urban and rural area-based partnerships to address issues of social exclusion in a more flexible, decentralised and participative way' (OECD, 1996, p. 5). This assessment of partnerships with various civil society groups as well as local authorities concentrated in disadvantaged areas was quickly followed by a number of OECD studies of the innovation potential of local partnerships for local development (OECD, 2001).

8. See http://www.oecd.org/cfe/leed/buildingmoreandbetterjobs.htm [Accessed 22 August 2014].

9. For this Forum, 'Social innovation deals with improving the welfare of individuals and community through employment, consumption or participation, its expressed purpose being therefore to provide solutions for individual and community problems'. http://www.oecd.org/cfe/leed/socialinnovation [Accessed 22 August 2014]. 
10. This definition received the imprimatur of the LEED Directing Committee (Noya, 2011). It is now consistently used as the OECD's definition of social innovation, sometimes with the claim that it is the first definition generated by an intergovernmental organisation and one of the first ever (OECD, 2010b, p. 196).

11. See the activities listed at http://www.oecd.org/employment/leed/leedforumonsocialinnovations.htm\#Activities [Accessed 22 August 2014].

12. http://ec.europa.eu/internal_market/social_business/index_en.htm [Accessed 30 September 2013]. This was intended to be a broad initiative. Other targets were multinationals and SMEs, including their involvement with environmental protection and acceptance of corporate responsibility. See the press release at http://europa.eu/rapid/press-release_IP-11-1238_ en.htm?locale=en [Accessed 22 August 2014].

13. A Google search (22 August 2014) on 'social business initiative' led to a web page titled 'social entrepreneurship'. The MNC and SME were nowhere to be found.

14. http://ec.europa.eu/internal_market/social_business/index_en.htm. This attention to social business with innovative potential is not to be confused with Innovation Union (http://ec.europa.eu/research/innovation-union/ index_en.cfm) which focuses on technological innovation and whose new 'innovation indicator' has nothing 'social' about it. See http://europa.eu/ rapid/press-release_IP-13-831_en.htm [All accessed 22 August 2014].

15. Given that social businesses, according to the European Union's conceptualisation, may contribute to smart, sustainable or inclusive growth, 'their key aim is to effect social and economic transformation that contributes to the objectives of the Europe 2020 Strategy' (European Commission, nd [2012], no page).

16. See the conference report at http://ec.europa.eu/internal_market/conferences/ 2014/0116-social-entrepreneurs/workshops/index_en.htm [Accessed 22 August 2014].

17. Sometimes this approach to social policy is termed the 'social investment state', following Giddens' (1998, Chapter 4) original formulation (e.g., Cantillon, 2011). I prefer the label 'social investment perspective' (Dobrowolsky and Jenson, 2005; Jenson 2010b) precisely because, as is argued here, more than the state corner of the welfare diamond and more than public authorities are involved in its promotion and implementation.

18. The social investment perspective should not be confused with the notion of 'social investments', one that has a long history and another meaning.

19. The European Union committed itself explicitly to the social investment perspective in 2012 and thus provided a succinct summary of the principles that had been in circulation for more than 15 years. See http://ec.europa.eu/ social/main.jsp?catId=1060\&langId=en, consulted 22 August 2014. See also Kvist (2013, pp. 91-2).

20. Similar innovations to incite the mobilisation of non-public providers were developed in the health and education domains (Blomqvist, 2004).

21. Family daycare providers were also part of the system, but they provided very little of the service (OECD, 2005).

22. The pace of growth was affected by the ongoing debates in Sweden over how to treat commercial childcare providers. The centre-right governments 
tended to want to allow them to receive public funds from both the central and municipal governments as any non-profit alternative form of care would, while the Swedish Social Democrats wanted to reserve public funding for non-profits. Korpi (2007) reviews these debates in detail.

23. http://www.ethicalbankingeurope.com/febea/legal/febea [Accessed 22 August 2014].

\section{References}

Bartsch, R. (2002) 'Generating Polysemy: Metaphor and Metonymy', in Dirven, R. and Pörings, R., Metaphor and Metonymy in Comparison and Contrast. Berlin: Walter de Gruyter, pp. 49-74.

Bernard, P. (1999) 'La cohésion sociale: Critique dialectique d'un quasi-concept', Lien social et Politiques, 41: 47-59.

Blomqvist, P. (2004) 'The Choice Revolution: Privatization of Swedish Welfare Services in the 1990s', Social Policy \& Administration, 38 (2): 139-55.

Bonoli, G. and Natali, D. (eds) (2012) The Politics of the New Welfare State. Oxford: Oxford University Press.

Bouchard, M.J. (2012) 'Social Innovation, an Analytical Grid for Understanding the Social Economy: The Example of the Québec Housing Sector', Service Business, 6: 47-59.

Cantillon, B. (2011) 'The Paradox of the Social Investment State: Growth, Employment and Poverty in the Lisbon Era', Journal of European Social Policy, 21 (5): 432-49.

Capacity (2008) Social Enterprise: A childcare solution for London? Available at http://www.capacityltd.org.uk/docs/Social_Enterprise_Report.pdf [Accessed 22 October 2014].

Caulier-Grice, J., Davies, A., Patrick, R. and Norman, W. (2012) Defining Social Innovation. A deliverable of the project: 'The theoretical, empirical and policy foundations for building social innovation in Europe' (TEPSIE), Brussels: European Commission.

Dobrowolsky, A. and Jenson, J. (2005) 'Social Investment Perspectives and Practices: A Decade in British Politics', in Powell, M., Bauld, L. and Clarke, K. (eds), Social Policy Review, 17. Bristol: Policy Press at the University of Bristol.

Duane-Richard, A. and Mahon, R. (2001) 'Sweden: Models in Crisis', in Jenson, J. and Sineau, M. (eds), Who Cares? Women's Work, Childcare, and Welfare State Redesigns. Toronto: University of Toronto Press.

Dustmann, C. and Frattini, T. (2011) 'Immigration. The European Experience'. Centro Studi Luca d'Agliano Development Studies Working Paper No. 326. Available at SSRN: http://ssrn.com/abstract=2023575 [Accessed 27 November 2014.]

Esping-Andersen, G., Gallie, D., Hemerijck, A. and Myles, J. (2002) Why We Need a New Welfare State. Oxford: Oxford University Press.

European Commission (2011a) An EU Framework for National Roma Integration Strategies up to 2020, $\operatorname{COM(2011)~} 173$ final.

European Commission (2011b) (nd) The Social Business Initiative. Promoting Social Investment Funds. Staff Working Paper. Brussels: DG Internal Market and Services.

European Commission (2012) (nd) The Social Business Initiative of the European Commission. Brussels: European Commission. 
European Commission (2013) Social Innovation Research in the European Union. Approaches, Findings and Future Directions. Policy Review. Brussels: European Commission.

Evers, A. and Guillemard, A-M. (eds) (2012) Social Policy and Citizenship. Oxford: Oxford University Press.

Evers, A., Ewert, B. And Brandsen, T. (eds) (2014) Social Innovations for Social Cohesion. Transnational Patterns and Approaches from 20 European Cities. Available at http://www.wilcoproject.eu/downloads/WILCO-project-eReader. pdf [Accessed 3 November 2014].

Evers, A., Pilj, M. and Ungerson, C. (eds) (1994) Payments for Care. A Comparative Overview. Aldershot: Avebury.

Fraser, N., Gutiérrez, R. and Peña-Casas, R. (eds) (2011) Working Poverty in Europe: A Comparative Approach. Work and Welfare in Europe Series. Basingstoke: Palgrave Macmillan.

Geobey, A., Westley, F. and Weber, O. (2012) 'Enabling Social Innovation through Developmental Social Finance', Journal of Social Entrepreneurship, 3 (2): 151-65.

Giddens, A. (1998) The Third Way. The Renewal of Social Democracy. Cambridge: Polity Press.

Hall, P.A. and Lamont, M. (eds) (2013) Social Resilience in the Neoliberal Era. New York: Cambridge University Press.

ILO [International Labour Organization] (2011) A Social Protection Floor for a Fair and Inclusive Globalization. Geneva: ILO.

Jenson, J. (2010a) Defining and Measuring Social Cohesion. London \& Geneva: Commonwealth Secretariat \& UNRISD.

Jenson, J. (2010b) 'Diffusing Ideas after Neo-liberalism: The Social Investment Perspective in Europe and Latin America', Global Social Policy, 10 (1): 59-84.

Jenson, J. (2012) 'A New Politics for the Social Investment Perspective: Objectives, Instruments and Areas of Intervention in Welfare Regimes', in Bonoli, G. and Natali, D. (eds), The Politics of the New Welfare State. Oxford: Oxford University Press, pp. 21-44.

Korpi, B.M. (2007) The Politics of Pre-School: Intentions and Decisions Underlying the Emergence and Growth of the Swedish Pre-School. 3rd Edition. Stockholm: Ministry of Education.

Kvist, J. (2013) 'The Post-Crisis European Social Model: Developing or Dismantling Social Investments?' Journal of International and Comparative Social Policy, 29 (1): 91-107.

Levitas, R. (2005) The Inclusive Society? Social Exclusion and New Labour. Basingstoke, Hampshire: Palgrave Macmillan.

Lyon, F. and Fernandez, H. (2012) Scaling Up Social Enterprise: Strategies Taken from Early Years Providers. Working paper 79. Birmingham: Third Sector Research Centre.

Mahon, R. and McBride, S. (2008) The OECD and Transnational Governance. Vancouver: University of British Columbia Press.

McNeill, D. (2006) 'The Diffusion of Ideas in Development Theory and Policy', Global Social Policy, 6 (3): 334-54.

Moulaert, F., Martinelli, F., Swyngedouw, E. and González, S. (eds) (2010) Can Neighbourhoods Save the City? Community Development and Social Innovation. Milton Park: Routledge. 
Nicholls, A. (2012) 'Postscript: The Legitimacy of Social Entrepreneurship; Reflexive Isomorphism in a Pre-paradigmatic Field', in Gidron, B. and Hasenfeld, Y. (eds), Social Enterprises. An Organizational Perspective. Basingstoke, Hampshire: Palgrave Macmillan, pp. 222-53.

Nicholls, A. and Murdock, A. (eds) (2012) Social Innovation: Blurring Boundaries to Reconfigure Markets. Basingstoke: Palgrave Macmillan.

Noya, A. (2011) 'Presentation', at the International Conference on Challenge Social Innovation. Innovating Innovation by Research. Vienna, 19-21 September.

OECD (1996) Local Partnerships and Social Innovation. Ireland. Paris: OECD.

OECD (2001) Local Partnerships for Better Governance. Paris: OECD.

OECD (2005) Babies and Bosses - Reconciling Work and Family Life. Volume 4. Canada, Finland, Sweden and the United Kingdom. Paris: OECD.

OECD (2008) Growing Unequal. Paris: OECD.

OECD (2010a) The OECD Innovation Strategy. Getting a Head Start on Tomorrow. Paris: OECD.

OECD (2010b) SMEs, Entrepreneurship and Innovation. Paris: OECD.

OECD (2011) Divided We Stand. Paris: OECD.

OECD (2014) OECD Family Database. Paris: OECD. Available at www.oecd.org/ social/family/database [Accessed 7 November 2014].

Osberg, T. and Schmidpeter, R. (eds) (2013) Social Innovation. Solutions for a Sustainable Future. Berlin: Springer.

Piore, M. and Sabel, C. (1984) The Second Industrial Divide. Possibilities for Prosperity. NYC: Basic Books.

Schumpeter, J. (1983) [1934] The Theory of Economic Development. An Inquiry into Profits, Capital, Credit, Interest and the Business Cycle. New Brunswick, NJ: Transaction.

SEL (Social Enterprise London) (2002) Social Enterprise Guide to Childcare. London: SEL.

Vidal, I. (2005) 'Social Enterprise and Social Inclusion: Social Enterprises in the Sphere of Work Integration', International Journal of Public Administration, 28 (9-10): 807-25.

Except where otherwise noted, this work is licensed under a Creative Commons Attribution 3.0 Unported License. To view a copy of this license, visit http://creativecommons.org/licenses/by/3.0/ 